\title{
INTERNATIONAL COMPARISON OF ELECTRICAL STANDARDS
}

\author{
By G. W. Vinal
}

\section{ABSTRACT}

Extended comparisons were made in 1931 of standards for the international ohm, ampere, and volt as maintained by the national laboratories of Germany, England, and the United States. Prof. Dr. H. von Steinwehr and Dr. A. Schulze, of the Physikalisch-Technische Reichsanstalt, P. Vigoureux, of the National Physical Laboratory, and the author met at the Reichsanstalt in Berlin and made joint experiments with the silver voltameter and in addition compared standard cells and resistances. This work was followed by comparisons of the cells and resistances at the Laboratoire Central d'Électricité in Paris and at the National Physical Laboratory in Teddington. This paper gives in detail the results of these comparisons and shows that there are differences in the values of standard cells and resistances which are large enough to suggest the necessity for a readjustment of the units as maintained by the laboratories. The silver voltameter measurements were in good agreement.

\section{CONTENTS}

I. Introduction

II. Arrangements at the P. T. R. for the work 729

III. Comparisons of standards for the ohm

1. At the Physikalisch-Technische Reichsanstalt

2. At the Laboratoire Central d'Electricité . . . . . . . . . . . . 733

3. At the National Physical Laboratory

4. Summary of comparisons of resistance coils $\ldots$

IV. Comparisons of standards of electromotive force

1. At the Physikalisch-Technische Reichsanstalt_........ 736

2. At the Laboratoire Central d'Électricité.

3. At the National Physical Laboratory _...

4. Comparison of four P. T. R. cells

5. Summary of comparisons on cells

v. Silver voltameter measurements _.

1. Electrical circuit. 741

2. Measurement of time 742

3. The voltameters

4. Preparation of platinum cups $\ldots \ldots$

5. Preparing the anodes

6. The electrolytes _... 743

7. Washing the deposits

8. Weighing the platinum cups $\ldots \ldots \ldots 74$

9. The silver deposits

10. Final results with the voltameter

VI. Discussion of differences in the units

VII. Conclusions

\section{INTRODUCTION}

Through the courtesy of the Physikalisch-Technische Reichsanstalt (PTR) at Berlin, extended comparisons were made in 1931 of the standards for the international ohm, ampere, and volt as maintained by 
the national laboratories of Germany, England, and the United States. Wire standards of resistance and standard cells were carried by hand to the Reichsanstalt for this comparison. A series of 10 experiments with the silver voltameter was made by representatives of the three laboratories to verify the values assigned to groups of Weston normal cells. Following the measurements in Berlin, the wire resistance standards and standard cells belonging to this bureau were carried to the Laboratoire Central d'Électricité (LCE) in Paris, and to the National Physical Laboratory (NPL) at Teddington, near London, for further comparisons. Two standard cells of the Reichsanstalt were also carried to these laboratories. At the conclusion of the measurements abroad the bureau's coils and cells and the two Reichsanstalt cells were brought to the Bureau of Standards (BS) for further measurement.

The initial and final values for both coils and cells at the Bureau of Standards differed by only a few parts in a million. This fact coupled with the several check measurements at the various laboratories affords highly consistent data by which an accurate estimate of the differences existing between the electrical standards of Germany, France, England, and the United States can be made.

In some respects the cooperative work done at the Reichsanstalt was similar to the work of the International Technical Committee at the Bureau of Standards in 1910. That committee, however, had the duty of recommending a uniform basis of measurement for the international ohm and of determining the value to be assigned to the Weston normal cell on the basis of the ohm and the voltameter measurements, which were made by the delegates. In doing this, the committee was carrying out the mandates of the International Conference on Electrical Units and Standards, London, 1908

The International Technical Committee ${ }^{1}$ recommended that the ohm should be based on the mean value of the mercury units of Germany and England. The unit thus defined has since been known as the "Washington unit." On the basis of this unit of resistance and the voltameter measurements the Technical Committee recommended the adoption of 1.0183 volts at $20^{\circ} \mathrm{C}$. as the electromotive force of the Weston normal cell. As a basis of measurement this is assumed to be exact to the sixth decimal, 1.018300 volts.

These recommendations of the technical committee were adopted by the International Committee on Electrical Units and Standards, which was then in existance, and by the national laboratories which began using these units on January 1, 1911. A uniform basis was thus provided for electrical measurements. Since then the national laboratories have maintained their standards by wire resistance coils and standard cells as each laboratory deemed best. Recourse to the mercury ohm ${ }^{2}$ and silver voltameter ${ }^{3}$ has been infrequent and, in general, such measurements have not been used to reassign values to the working standards. This is not a matter of neglect, but rather a tacit recognition of the fact that the units for the ohm and the volt

${ }^{1}$ Report to the International Committee on Electrical Units and Standards, published by Bureau of Standards, M16, 1912.

2 Die Quecksilbernormale der PTR für das Ohm (Fortsetzung V), von Steinwehr und Schulze, 1927.

Determinations by Smith 1912 and Hartshorn 1924 . Reports of NPL, p. 40, 1912; p. 93, 1925. Construction of Primary Mercurial Resistance Standards, Wolff, Shoemaker, and Briggs, B. S. Bulletin, vol. 12, p. $375,1915$.

3 Nachprüfung der EMK des internationalen Westonelements mit Hilfe des Silbervoltameters, von Steinwehr und Schulze, Zeit. f. Instrk., vol. 42, p. 221, 1922. 
can be maintained for a reasonable length of time to a higher degree of constancy by suitable wire standards of resistance and standard cells than by frequent experiments with the mercury ohm and the silver voltameter.

Twenty-one years have elapsed since this agreement providing a uniform basis became effective. Intercomparisons of standards of electromotive force between several of the national laboratories in the years 1929 and 1930 indicated significant differences to exist between the standards of this bureau and the Reichsanstalt and lesser differences between the bureau and the National Physical Laboratory. The principal object of the present work, therefore, was to make voltameter measurements at the German laboratory simultaneously with representatives of the other laboratories with a view to explaining these differences. The opportunity for this comparative work came through arrangements previously made between the Bureau of Standards and the Reichsanstalt for an exchange of personnel in the year 1931. Prof. Dr. Henning, of the Reichsanstalt, took part in investigations on the temperature scale at the bureau for a period of about two months and the author spent about the same time in Berlin. Because of the interest of other laboratories in this cooperative investigation, Mr. Vigoureux, of the National Physical Laboratory, came to Berlin, at the invitation of the Reichsanstalt, to take part in the intercomparison.

\section{ARRANGEMENTS AT THE, P.T. R. FOR THE WORK}

The work was done in the Elektrische Abteilung, of which Prof. Dr. Giebe is the director. The laboratory for Elektrische Einheiten und Messungen is in charge of Prof. Dr. von Steinwehr who, with Doctor Schulze, cooperated in the measurements reported in this paper. Others who assisted were Doctor Gremmer, Herr Kessner, Herr Gutmann, and Herr Höft. Grateful acknowledgment is due to these gentlemen and to Mr. Vigoureux, of the National Physical Laboratory, for their friendly cooperation in the course of this work.

The constant-temperature room in which the standard cells are kept and in which the voltameter experiments were made is located in the Observatory Building. An office with laboratory facilities was also provided in this building for the use of Mr. Vigoureux and the author.

By agreement the results are being published by the several laboratories independently after review by the other laboratories which were concerned in the work.

\section{COMPARISONS OF STANDARDS FOR THE OHM}

Before discussing the results of the voltameter measurements at Berlin it is desirable to present the comparisons of standards for the $\mathrm{ohm}$ and volt. Three wire resistance standards of the bureau, ${ }^{4}$ which were carried by hand, have been measured by the laboratories at Berlin, Paris, and Teddington. Measurements of these coils at the bureau in May preceding and in October following the measurements abroad are given in Table 1 . The mean value for the group of coils

4 The construction of these coils has been described by Thomas, B. S. Jour. Research, vol. 5, p. 295, 1930.

$117348-32-5$ 
is identically the same in May as in October, indicating that the coils have suffered no change by being carried to the foreign laboratories. The bureau's values are expressed in terms of the Washington unit as preserved by a group of 10 coils constituting the bureau's primary reference group.

\section{AT THE PHYSIKALISCH-TECHNISCHE REICHSANSTALT}

The unit employed in 1910 by the Reichsanstalt for certifying resistances to the public was within 5 parts in 1,000,000 of the "Washington unit," agreed upon by the International Technical Committee. Their unit has been preserved by four resistance coils. Occasional comparisons of these coils have been made with mercury tubes, however, and these measurements indicate a gradual increase in the resistance of these coils amounting on the average to about 1 microhm per year. The last comparison ${ }^{5}$ with the mercury tubes was in 1923-1925, and the result showed that the unit as preserved by the Reichsanstalt coils is larger than their mercury-ohm unit by $33 \times 10^{-6}$. For present international comparisons, the Reichsanstalt has chosen to express the results in terms of "international ohms" based upon their latest mercury-ohm experiments; that is to say, the values of the bureau's coils measured against their coils have been increased by $33 \times 10^{-6}$.

Two methods of comparing resistance standards were employed. The first measurements were made by the differential galvanometer method. ${ }^{6}$ The secon'd set of measurements was made on the Kelvin bridge. ${ }^{7}$

TABLE 1.-Comparison of measurements at the Bureau of Standards on resistance coils before and after the measurements abroad

[Bureau of Standards coils]

\begin{tabular}{|c|c|c|c|c|}
\hline 4 & Coil No. & $\begin{array}{c}\text { Temper- } \\
\text { ature }\end{array}$ & May, 1931 & $\begin{array}{c}\text { October, } \\
1931\end{array}$ \\
\hline $\begin{array}{l}37 \\
42 \\
54\end{array}$ & & $\begin{array}{r}{ }^{\circ} \mathrm{C} . \\
20 \\
20 \\
20\end{array}$ & $\begin{array}{r}\text { Int. ohms } \\
0.999917 \\
.999823 \\
.999457\end{array}$ & $\begin{array}{r}\text { Int. ohms } \\
0.999917 \\
.999824 \\
.999455\end{array}$ \\
\hline \multicolumn{2}{|c|}{ Mean } & -......... & .999732 & .999732 \\
\hline
\end{tabular}

Note.-The October values confirm the May values, which are used in subsequent tables.

TABLE 2.-Comparison of resistance coils at the Physikalisch-Technische Reichsanstalt, 1931

[Measurements on Bureau of Standards coils at $20^{\circ} \mathrm{C}$.]

\begin{tabular}{|c|c|c|c|c|c|}
\hline Coil No. & June & July & $\begin{array}{l}\text { Mean } \\
\text { P.T. R. } \\
\text { values }\end{array}$ & $\begin{array}{l}\text { B. } S . \\
\text { values } \\
\text { (May) }\end{array}$ & PTR-BS \\
\hline 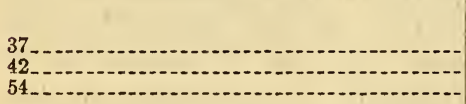 & $\begin{array}{r}\text { Int. ohms } \\
0.999908 \\
.999815 \\
.999449\end{array}$ & $\begin{array}{r}\text { Int. ohms } \\
0.999908 \\
.999813 \\
.999448\end{array}$ & $\begin{array}{r}\text { Int. ohms } \\
0.999908 \\
.999814 \\
.999448\end{array}$ & $\begin{array}{r}\text { Int. ohms } \\
0.999917 \\
.999823 \\
.999457\end{array}$ & $\begin{aligned} & \text { Microhms } \\
&-9 \\
&-9 \\
&-9\end{aligned}$ \\
\hline Mean difference...... & & & $\theta$ & ..... & -9 \\
\hline
\end{tabular}

Nore.-The June measurements were made at $20.17^{\circ}, 20.31^{\circ}$, and $20.39^{\circ}$, respectively, and the results calculated to $20^{\circ}$.

${ }^{3}$ See footnote 2, p. 730.

- Geiger u. Scheel, Handbuch der Physik, vol. 6, p. 455.

7 Idem. p. 452. 
TABLE 3.-Comparison of resistance coils at the Laboratoire Central d'Électricite, 1981

[Measurements on Bureau of Standards coils at $20^{\circ} \mathrm{C}$.]

\begin{tabular}{|c|c|c|c|}
\hline Coil No. & $\begin{array}{l}\text { L. C. E. } \\
\text { certificate } \\
\text { values }\end{array}$ & $\begin{array}{c}\text { B. S. } \\
\text { values }\end{array}$ & LCE-BS \\
\hline 42, & $\begin{array}{r}\text { Int. ohms } \\
0.999817 \\
.999753 \\
.999387\end{array}$ & $\begin{array}{r}\text { Int. ohms } \\
0.999917 \\
.999823 \\
.999457\end{array}$ & $\begin{aligned} \text { Microhms } & \\
& =70 \\
& =70 \\
& -70\end{aligned}$ \\
\hline Mean difference & & & -70 \\
\hline
\end{tabular}

Table 2 gives the measurements on the bureau's coils at the Reichsanstalt and shows that the mean difference between the P. T. R. and the B.S. values is 9 microhms. The P.T.R. values are smaller than the values certified by the bureau, which indicates that the P. T. R. unit is larger by this amount.

\section{AT THE LABORATOIRE CENTRAL D'ÉLECTRICITÉ}

The wire resistance standards (and cells also) have been measured at the Laboratorie Central d'Électricité through the courtesy of M. Jouaust and M. Picard. The unit of resistance maintained at this laboratory is the Washington unit.

Table 3 gives the results of measurements on the bureau's coils at the L. C. E. The difference from the bureau's standards is 70 microhms. The L. C. E. values are smaller than the B. S. values, indicating that the L. C. E. unit is larger. There have been no previous comparisons of $\mathrm{B}$. S. standards with $\mathrm{L}$. C. E. standards for the past 20 years. A comparison ${ }^{8}$ between the standards of the L. C. E. and the P. T. R. was made in 1929 and the results at that time agree with the present measurements to within 8 microhms.

\section{AT THE NATIONAL PHYSICAL LABORATORY}

Following the measurements in Paris the resistance coils were taken to London for measurement at the National Physical Laboratory. The author is indebted to Doctor Dye and Mr. Vigoureux for their cooperation in these comparisons in which they were assisted by $\mathrm{Mr}$. Watts.

The Washington unit has been preserved at the N. P. L. by four 1-ohm manganin coils which have consistently held the same relative values. Between 1912 and 1930 the relative variation of any one coil from the mean of 4 is stated to be less than 1 part in 100,000 . The N. P. L. has, however, chosen for the present international experiments to express its unit for the ohm as the "international ohm" based upon mercury-ohm determinations made by Smith ${ }^{9}$ in 1912, and by Hartshorn ${ }^{9}$ in 1924 . Smith found the Washington unit as preserved by their coils greater than his mercury unit by $16 \times 10^{-6}$ and Hartshorn found it $41 \times 10^{-6}$ greater. The laboratory has therefore chosen $30 \times 10^{-6}$ as a round figure expressing the mean of these two results, and the values here reported for the bureau's coils

${ }^{8}$ A report of these measurements was published in the Rapport, Comité Consultatif d'Électricitê, 1930, p. 123.

See footnote 2, p. 730. 
are $30 \times 10^{-6}$ greater than the results of measurements in terms of the Washington unit as preserved at the N. P. L.

The method employed for the intercomparison of resistance standards is described in Glazebrook's Dictionary of Physics. ${ }^{10}$

Table 4 gives the results of measurements on the bureau's coils at the National Physical Laboratory. The average difference indicates that the N. P. L. "international ohm" is smaller than the B. S. "Washington unit" by 4 microhms which agrees with the difference calculated from the Berlin measurements (see Table 5) to within 1 microhm.

TABLE 4.-Comparison of resistance coils at National Physical Laboratory, 1931 [Measurements on Bureau of Standards coils at $20^{\circ} \mathrm{C}$.]

\begin{tabular}{|c|c|c|c|c|}
\hline t & Coil No. & $\begin{array}{l}\text { Mean N. P } \\
\text { L. values }\end{array}$ & $\begin{array}{c}\text { B. S. } \\
\text { values }\end{array}$ & NPL-BS \\
\hline $37-34$ & & $\begin{array}{r}\text { Int. ohms } \\
0.999924 \\
.999826 \\
.999458\end{array}$ & $\begin{array}{r}\text { Int. ohms } \\
0.999917 \\
.999823 \\
.999457\end{array}$ & $\begin{array}{r}\text { Microhms } \\
7 \\
3 \\
1\end{array}$ \\
\hline Mean d & & & & 4 \\
\hline
\end{tabular}

TABLE 5.-Summary of resistance coil comparisons, 1931

[Differences of the measured values in microhms]

\begin{tabular}{|c|c|c|c|c|c|c|c|}
\hline \multirow{2}{*}{ Place of measurement } & \multicolumn{2}{|c|}{ Coils } & \multirow{2}{*}{ Comparison } & \multirow{2}{*}{$\underset{\mathrm{BS}}{\mathrm{PTR}}$} & \multirow{2}{*}{$\begin{array}{l}\text { PTR- } \\
\text { NPL }\end{array}$} & \multirow{2}{*}{$\underset{B S}{\text { NPL- }}$} & \multirow{2}{*}{ BCE- } \\
\hline & Source & No. & & & & & \\
\hline Berlin & N. P. L & $\begin{array}{l}3 \\
3\end{array}$ & Direct-_-_- & -9 & -12 & & \\
\hline aris. & $\begin{array}{l}\mathrm{BS} \text { and NP} \\
\text { B. S }\end{array}$ & $\begin{array}{r}3-3 \\
3\end{array}$ & $\begin{array}{l}\text { By difference. } \\
\text { Direct }\end{array}$ & & & +3 & \\
\hline London- & D. & 3 & -..-do_. & & $-\ldots .$. & +4 & \\
\hline Mean differences. & & & & -9 & -12 & +4 & -70 \\
\hline
\end{tabular}

Note.-A minus sign means that the measured value at the laboratory first named is less than the measured value at the second. In comparing the magnitude of the unit, however, it is obvious that the larger the unit, the smaller will be the measured value for the coils.

\section{SUMMARY OF COIMPARISONS OF RESISTANCE COILS}

Table 5 gives a summary of all the measurements on resistance coils, inciuding a comparison with three coils of the N. P. L. which were measured at Berlin, but for which the detailed figures are not given in this paper. The maximum difference of the values is 74 microhms, which exists between the French and British laboratories. Since the measured values are larger as the unit is smaller, the differences for the coils as given in Table 5 have been translated into differences in the units and are shown graphically in Figure 1. The larger units in each case are at the top of the figure.

${ }^{10}$ Volume II, p. 717. 


\section{COMPARISON OF STANDARDS OF ELECTROMOTIVE FORCE}

Comparisons of the standards of electromotive force have been made also at the three laboratories. The standard cells which were carried abroad for these measurements are listed in Table 6. Six of these cells have been brought back to the bureau and remeasured. The differences are slightly greater than in the case of standards for the ohm, but the mean value of the cells which were brought back to

Differences in Millionths
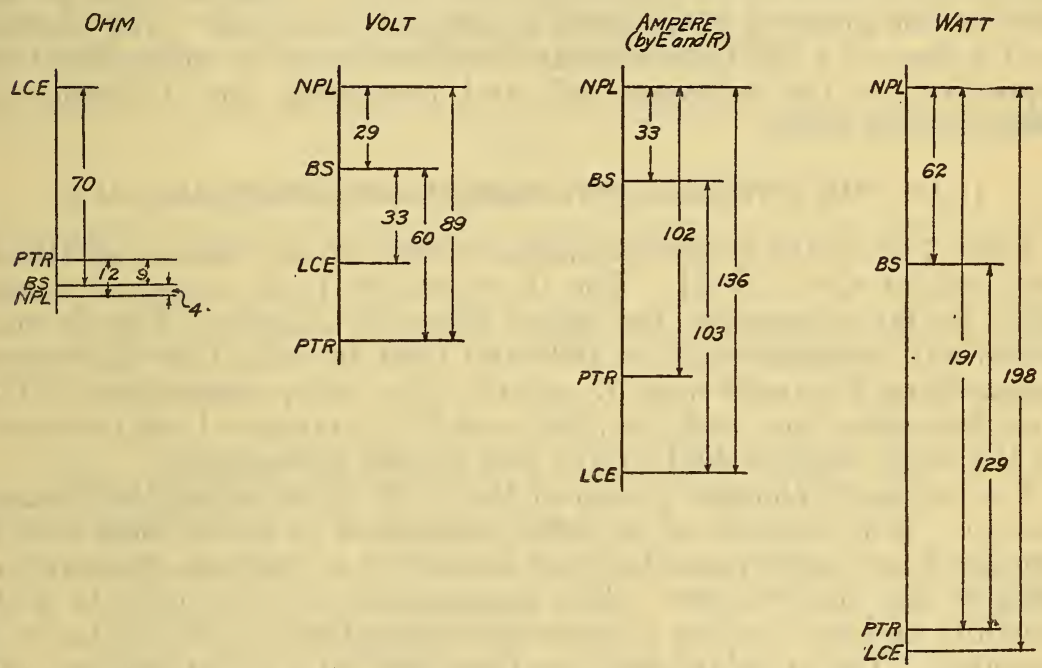

FIGURE 1.-Relative values of units as found in international comparisons of 1931

the bureau differs from the mean of the same cells in May by only 2 microvolts.

TABLE 6.-Comparison of measurements at the Bureau of Standards on standard cells before and after measurements abroad

[Bureau of Standards cells, $\left.28^{\circ} \mathrm{C}.\right]^{2}$

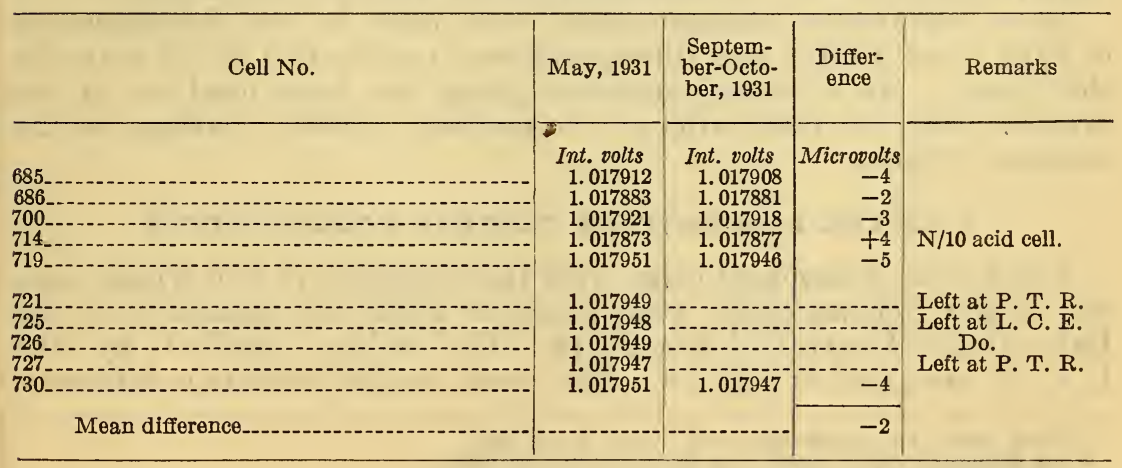


The maintenance of the standard for the volt at the Bureau of Standards has been described ${ }^{11}$ previously. The primary reference group at the present time consists of 20 cells, 15 of which were made 26 years ago. These cells have shown a remarkable degree of constancy. The group is kept at a constant temperature of $28^{\circ} \mathrm{C}$. in an oil bath which is provided with thermostatic control. The value assigned to the average electromotive force of the group corresponds to the value 1.0183 international volts at $20^{\circ} \mathrm{C}$. for the Weston normal cell. The electromotive forces of the cells themselves, however, are slightly lower than for Weston normal cells. No corrections for a yearly decrease in voltage have been found necessary. One cell in this group is used as the reference cell, and its value in terms of the mean of the group is determined at frequent intervals. The electromotive force of a cell to be measured is determined by connecting it in opposition to the reference cell and measuring the difference in electromotive force.

\section{AT THE PHYSIKALISCH-TECHNISCHE REICHSANSTALT}

Table 7 gives the results of measurements on the Bureau of Standards cells at the P. T. R. The B. S. and P. T. R. measured values differ by 60 microvolts, the latter being the higher. This is consistent with measurements in 1929 and 1930, for which the differences measured on four cells were 57 and 60 microvolts, respectively. The same four cells, Nos. 685, 686, 700, and 714, have now been measured for the third time at the German and British laboratories.

The primary reference group of the P. T. R. is called the Kleiner Stamm. It is a group of 10 cells maintained in an oil bath that is contained in a large insulated case located in a constant-temperature room in the observatory. The temperature of this room is quite constant and no further temperature regulation of the oil baths is provided. The standard cells are measured on a potentiometer, one of the cells of the Kleiner Stamm being taken as the reference cell. The 10 cells included in this group are part of a slightly larger group which was brought to the bureau in 1910 by Doctor Jaeger at the time of the international technical committee. The mean value of the whole group in 1910 was found to be the same as the mean of the group means of the cells submitted by the four laboratories at that time and to this mean of the group means was assigned the value 1.0183 volts at $20^{\circ} \mathrm{C}$. as representing the Weston normal cell.

Silver voltameter measurements were made by the Reichsanstalt in $1913^{12}$ and $1921,{ }^{13}$ and these confirmed the figure 1.01830 volts for this group. As a consequence the group has been used up to the present time for international comparisons without change in the assigned value.

\section{AT THE LABORATOIRE CENTRAL D'ÉLECTRICITÉ}

The bureau's standard cells, with the exception of two which were left at the Reichsanstalt, were taken to Paris and measured at the Laboratoire Central d'Electricité. The values certified by the L. C. E. are given in Table 8. The mean results indicate a difference

11 Vinal, Trans. Am. Electrochem. Soc., vol. 54, p. 249, 1928.

12 von Steinwehr, Zeit. f. Instrk., vol. 33, pp. 321 and $353,1913$.

13 von Steinwehr and Schulze, Zeit. f. Instrk., vol. 42, p. 221, 1922. 
in the measured values of electromotive force of the cells amounting to 34 microvolts, the bureau's values being the smaller.

\section{AT THE NATIONAL PHYSICAL LABORATORY}

The bureau's cells, except two which were left in Paris, were taken to the Nationa! Physical Laboratory for measurement. At the N. P. L. a number of standard cells are made each year. The unit which is employed at this laboratory is based on the value 1.018300 for the neutral Weston cell at $20^{\circ} \mathrm{C}$. The cells, however, are tenthnormal acid cells and have an electromotive force 62 microvolts lower than the neutral cells. After corrections for acidity and temperature have been made the proper value is assigned to the mean of the groups of cells made during the five preceding years.

TABLE 7.-Standard cell comparisons at the Physikalisch-Technische Reichsanstalt, 1931

[Measurements on Bureau of Standards cells, $20^{\circ} \mathrm{C}$.]

[Actual temperature during measurement: P. T. R. $19.98^{\circ}$ to $20.35^{\circ}$ C., B. S. values calculated to $20^{\circ}$ C. from measurements at $28^{\circ}$ and $25^{\circ} \mathrm{C}$.]

\begin{tabular}{|c|c|c|c|c|c|c|c|c|c|c|c|c|c|c|}
\hline $\begin{array}{l}\text { Coll } \\
\text { No. }\end{array}$ & $\underset{5}{J u n e}$ & $\begin{array}{c}\text { June } \\
12\end{array}$ & $\mathrm{Jun}_{24}$ & $\underset{26}{J u n e}$ & $\begin{array}{l}\text { June } \\
30\end{array}$ & $\underset{2}{\text { July }}$ & July & July & $\begin{array}{c}\text { July } \\
14\end{array}$ & $\begin{array}{c}\text { July } \\
18\end{array}$ & Mean & $\begin{array}{l}\text { B. S. } \\
\text { values, } \\
\text { May } 11\end{array}$ & PTR- & Remarks \\
\hline $\begin{array}{l}685--- \\
686 \ldots--- \\
700 \ldots-- \\
714 \ldots\end{array}$ & $\begin{array}{r}1.018352 \\
323 \\
369 \\
317\end{array}$ & $\begin{array}{l}352 \\
323 \\
373 \\
317\end{array}$ & $\begin{array}{l}351 \\
321 \\
371 \\
315\end{array}$ & $\begin{array}{l}348 \\
320 \\
369 \\
313\end{array}$ & $\begin{array}{l}349 \\
321 \\
368 \\
314\end{array}$ & $\begin{array}{l}351 \\
322 \\
368 \\
317\end{array}$ & $\begin{array}{l}352 \\
321 \\
372 \\
317\end{array}$ & $\begin{array}{l}347 \\
326 \\
376 \\
318\end{array}$ & & & $\begin{array}{r}\text { Int. } \\
\text { volts } \\
\text { 1. } 018350 \\
322 \\
371 \\
316\end{array}$ & $\begin{array}{c}\text { Int. } \\
\text { oolts } \\
\text { 1. } 018292 \\
263 \\
301 \\
253\end{array}$ & $\begin{array}{c}\text { Micro- } \\
\text { volts } \\
58 \\
59 \\
70 \\
63\end{array}$ & \multirow{5}{*}{$\begin{array}{l}\text { Open circuit } \\
\text { repaired. } \\
\text { Left at PTR } \\
\text { Do. }\end{array}$} \\
\hline $719 \ldots$ & 382 & & & & & - & 391 & 392 & & & 388 & 328 & 60 & \\
\hline $\begin{array}{l}721 \ldots \\
725 \ldots- \\
726 \ldots\end{array}$ & $\begin{array}{l}384 \\
383 \\
384\end{array}$ & $\begin{array}{l}382 \\
385 \\
382\end{array}$ & $\begin{array}{l}384 \\
383 \\
385\end{array}$ & $\begin{array}{l}384 \\
383 \\
383\end{array}$ & $\begin{array}{l}383 \\
382 \\
383\end{array}$ & $\begin{array}{l}382 \\
382 \\
385\end{array}$ & $\begin{array}{l}386 \\
383 \\
385\end{array}$ & $\begin{array}{l}381 \\
391 \\
389\end{array}$ & \begin{tabular}{c}
377 \\
\hdashline
\end{tabular} & 377 & $\begin{array}{l}382 \\
384 \\
384\end{array}$ & $\begin{array}{l}326 \\
325 \\
326\end{array}$ & $\begin{array}{l}56 \\
59 \\
58\end{array}$ & \\
\hline $\begin{array}{l}727 \ldots \\
730\end{array}$ & $\begin{array}{l}379 \\
388\end{array}$ & $\begin{array}{l}384 \\
389\end{array}$ & $\begin{array}{l}387 \\
389\end{array}$ & $\begin{array}{l}379 \\
387\end{array}$ & $\begin{array}{l}379 \\
386\end{array}$ & $\begin{array}{l}380 \\
389\end{array}$ & $\begin{array}{l}381 \\
387\end{array}$ & $\begin{array}{l}387 \\
388\end{array}$ & $\begin{array}{r}376 \\
-\end{array}$ & 372 & $\begin{array}{l}380 \\
388\end{array}$ & $\begin{array}{l}325 \\
326\end{array}$ & $\begin{array}{l}55 \\
62\end{array}$ & \\
\hline Mean & 1.018366 & 365 & 365 & 363 & 363 & 364 & 367 & 369 & --- & $\cdots$ & 1. 018366 & 1. 018306 & 60 & \\
\hline
\end{tabular}

TABLE 8.-Standard cell comparisons at the Laboratoire Central d'Electricite, 1931

[Measurements on Bureau of Standards cells, $20^{\circ} \mathrm{C}$.]

[L.C.E. measurements at $20.0^{\circ}$ to $20.7^{\circ} \mathrm{C}$; B.S. values calculated to $20^{\circ} \mathrm{C}$. from measurements at $28^{\circ}$ and $25^{\circ}$.]

\begin{tabular}{|c|c|c|c|c|}
\hline Cell No. & $\begin{array}{l}\text { L. C. E. } \\
\text { certified } \\
\text { values }\end{array}$ & B. S. values & LCE-BS & Remarks \\
\hline 68560 & $\begin{array}{r}\text { Int. volts } \\
1.018329 \\
304 \\
328 \\
297\end{array}$ & $\begin{array}{r}\text { Int. volts } \\
1.018292 \\
263 \\
301 \\
253\end{array}$ & $\begin{array}{r}\text { Microvolts } \\
37 \\
41 \\
27 \\
44\end{array}$ & \multirow{3}{*}{$\begin{array}{c}\text { Left at L. C. E. } \\
\text { Do. }\end{array}$} \\
\hline 725 & $\begin{array}{l}353 \\
352 \\
358 \\
365\end{array}$ & $\begin{array}{l}328 \\
325 \\
326 \\
326\end{array}$ & $\begin{array}{l}25 \\
27 \\
32 \\
39\end{array}$ & \\
\hline Mean. & 1.018336 & 1.018302 & 34 & \\
\hline
\end{tabular}


TABLE 9.-Standard cell comparisons at the National Physical Laboratory, 1931

[Measurements on Bureau of Standards cells at $20^{\circ} \mathrm{C}$.]

[N. P. L. values at $20^{\circ}$ C.; B. S. values calculated to $20^{\circ}$ from measurements at $28^{\circ}$ and $25^{\circ}$ ]

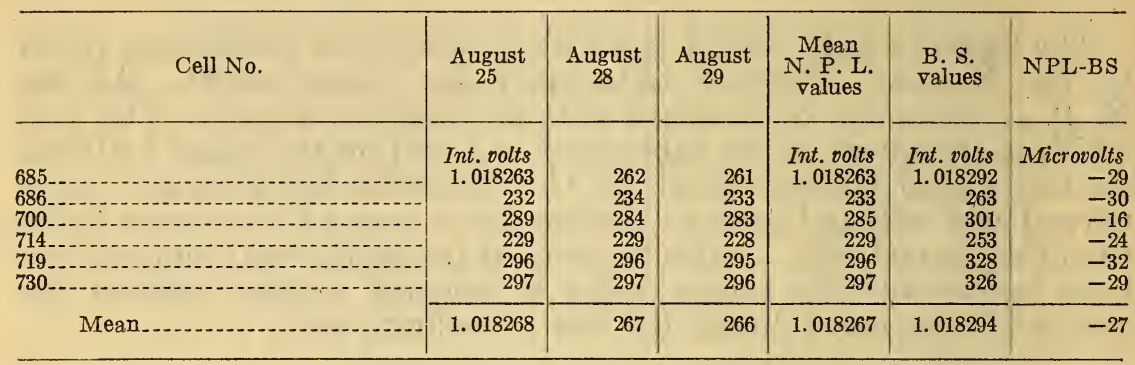

Table 9 gives the measurements on the Bureau of Standards cells at $20^{\circ} \mathrm{C}$., correpsonding in this respect with the measurements made in Berlin and Paris. The difference between the measured values is 27 microvolts, the bureau's values in this case being larger than those of the N. P. L.

Because of the importance of temperature corrections in making these measurements the bureau's cells were also measured at the N. P. L. at $16^{\circ}, 25^{\circ}$, and $28^{\circ}$ C. The results are given in Table 10. It will be observed that the difference between the N.P. L. and the bureau's measurements decreased as the temperature was increased. This can be explained on the theory that the cells do not exactly follow the international temperature formula. For the purpose of the present comparison, however, the measurements at $20^{\circ} \mathrm{C}$. were chosen, since this was the procedure followed by other laboratories.

TABLE 10.-Standard cell comparisons at the National Physical Laboratory, 1981

[Summary of measurements at N.P. L. on Bureau of Standards cells at 4 temperatures. Results expressed as differences in microvolts.]

\begin{tabular}{|c|c|c|c|c|c|}
\hline . & Cell No. & $\begin{array}{l}\text { At } 16^{\circ} \mathrm{C} . \\
\text { NPL-BS }\end{array}$ & $\begin{array}{l}\text { At. } 20^{\circ} \mathrm{C} . \\
\text { NPL-BS }\end{array}$ & $\begin{array}{l}\text { At } 25^{\circ} \mathrm{C} \text {. } \\
\text { NPL-BS }\end{array}$ & $\begin{array}{l}\text { At } 28^{\circ} \mathrm{C} . \\
\text { NPL-BS }\end{array}$ \\
\hline $\begin{array}{l}685 \\
78600 \\
714 \text { (acid) } \\
7190 \\
730\end{array}$ & & $\begin{array}{l}-33 \\
-36 \\
-29 \\
-33 \\
-38 \\
-37\end{array}$ & $\begin{array}{l}-29 \\
-30 \\
-16 \\
-24 \\
-32 \\
-29\end{array}$ & $\begin{array}{l}-26 \\
-27 \\
-23 \\
-22 \\
-30 \\
-29\end{array}$ & $\begin{array}{l}-23 \\
-22 \\
-23 \\
-14 \\
-26 \\
-24\end{array}$ \\
\hline Mean & - & -34 & -27 & -26 & -22 \\
\hline
\end{tabular}

Comparisons of four bureau cells (Nos. 685, 686, 700, 714) were made at the N. P. L. in 1929 and 1930 at a temperature of $28^{\circ}$ C. corresponding to the temperature employed at the Bureau of Standards for the measurement of these cells. The mean difference for these four cells measured at $28^{\circ} \mathrm{C}$. agrees closely with measurements of 1929 and 1930 as shown in Table 11. 
TABLE 11.-Comparison of four B. S. cells at the N.P. L. for the years 1929, 1930, and 1931

[Measurements made at $28^{\circ} \mathrm{C}$.]

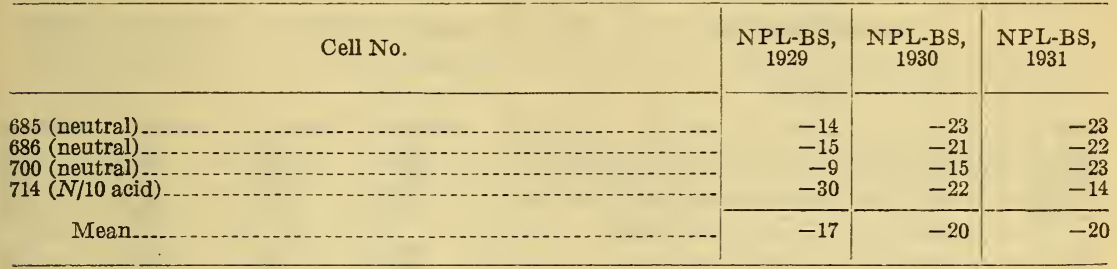

While the mean values for the difference between N. P. L. and B. S. measurements on these cells are very closely the same for the three years, it is noticeable that the individual differences of the neutral cells are increasing with time, but the reverse is true of the acid cell. This supports a conclusion reached at the bureau some time ago on the basis of other evidence that a study of the temperature coefficient of the saturated cell as a function of age is needed.

\section{COMPARISON OF FOUR PHYSIKALISCH-TECHNISCHE REICHSAN- STALT CELLS}

A comparison between the various laboratories has also been made on the basis of measurements of cells belonging to the PhysikalischTechnische Reichsanstalt. Two of these cells were given to the delegate from the National Physical Laboratory and two to the author. The latter cells have been measured in Paris, London, and Washington, the former have been measured in London only.

Table 12 gives the complete results on these cells beginning with measurements made at the Reichsanstalt. These measurements confirm those of the other groups of cells described previously.

\section{SUMMARY OF COMPARISONS ON CELLS}

The standard cell comparisons are summarized in Table 13 in which it is shown that the measurements at the different laboratories are consistent to a high degree. The four comparisons between the P: T. R. standards and the bureau's standards were concordant to within 1 part in 100,000 although the measurements were made in four different laboratories. The final results have been weighted in accordance with the number of cells in the group. When comparisons were made of two groups the result has been assigned a weight proportional to the smaller number of cells. The minus signs have the same significance in this table as in Table 5. Differences in the unit maintained for the volt in these laboratories are shown graphically in Figure 1. In general, these results are in fair agreement with comparisons reported by Takatsu and Jimbo. ${ }^{14}$

I* Rapport, Comité Consultatif d’Électricité, p. 119, 1930. 
TABLE 12.-Comparison of four Physikalisch-Technische Reichsanstalt cells at the Laboratoire Central d'Électricite, the National Physical Laboratory, and the Bureau of Standards, $20^{\circ} \mathrm{C}$.

\begin{tabular}{|c|c|c|c|c|}
\hline Date and place, 1931 & 3,116 & 3,115 & 3,118 & 3,117 \\
\hline $\begin{array}{l}\text { June } 5 \text {. } \\
\text { June } 12 \\
\text { June } 24 \\
\text { June } 26 \ldots-\ldots \\
\text { June } 30 \ldots \ldots\end{array}$ & $\begin{array}{r}1.018419 \\
420 \\
418 \\
420 \\
416\end{array}$ & $\begin{array}{r}1.018421 \\
423 \\
419 \\
421 \\
417\end{array}$ & $\begin{array}{r}1.018417 \\
418 \\
415 \\
418 \\
414\end{array}$ & $\begin{array}{r}1.018418 \\
419 \\
416 \\
419 \\
415\end{array}$ \\
\hline $\begin{array}{l}\text { July } 2 \\
\text { July } 6 \\
\text { July } 9 \\
\text { July } 14 \\
\text { July } 18\end{array}$ & $\begin{array}{r}419 \\
424 \\
420 \\
(414) \\
(412)\end{array}$ & $\begin{array}{r}421 \\
422 \\
418 \\
(414) \\
(412)\end{array}$ & $\begin{array}{r}416 \\
419 \\
419 \\
\\
\end{array}$ & $\begin{array}{r}418 \\
418 \\
418 \\
(410) \\
\end{array}$ \\
\hline Mean & 1.018420 & 1.018420 & 1. 018417 & 1. 018418 \\
\hline 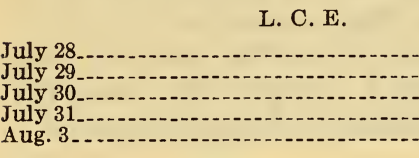 & & - & $\begin{array}{r}\text { 1. } 018389 \\
403 \\
390 \\
389 \\
394\end{array}$ & $\begin{array}{r}1.018394 \\
405 \\
389 \\
389 \\
392\end{array}$ \\
\hline Mean..... & - n & (n) & 1. 018393 & 1. 018394 \\
\hline $\begin{array}{l}\text { Aug. 25 } \\
\text { Aug. 28 } \\
\text { Aug. 29 }\end{array}$ & $\begin{array}{r}1.018327 \\
324 \\
326\end{array}$ & $\begin{array}{r}1.018325 \\
326 \\
327\end{array}$ & $\begin{array}{r}1.018326 \\
324 \\
324\end{array}$ & $\begin{array}{r}1.018332 \\
327 \\
326\end{array}$ \\
\hline Mean ...... & 1. 018326 & 1. 018326 & 1. 018325 & 1. 018328 \\
\hline $\begin{array}{l}\text { B. S. } \\
\text { Sept. } 23 \\
\text { Sept. } 24 \\
\text { Sept. } 25 \\
\text { Sept. } 29 \\
\text { Oct. } 12 \\
\text { Oct. } 2 \\
\text { Oct. } 5\end{array}$ & 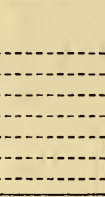 & 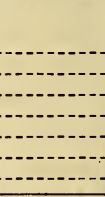 & $\begin{array}{r}\text { 1. } 018347 \\
349 \\
348 \\
349 \\
349 \\
349 \\
350 \\
\end{array}$ & $\begin{array}{r}\text { 1. } 018352 \\
352 \\
352 \\
352 \\
352 \\
352 \\
351 \\
\end{array}$ \\
\hline Mean & & $-\cdots$ & 1. 018349 & 1. 018352 \\
\hline
\end{tabular}

TABLE 13.-Summary of standard cell comparisons, 1931

[Differences in microvols, ]

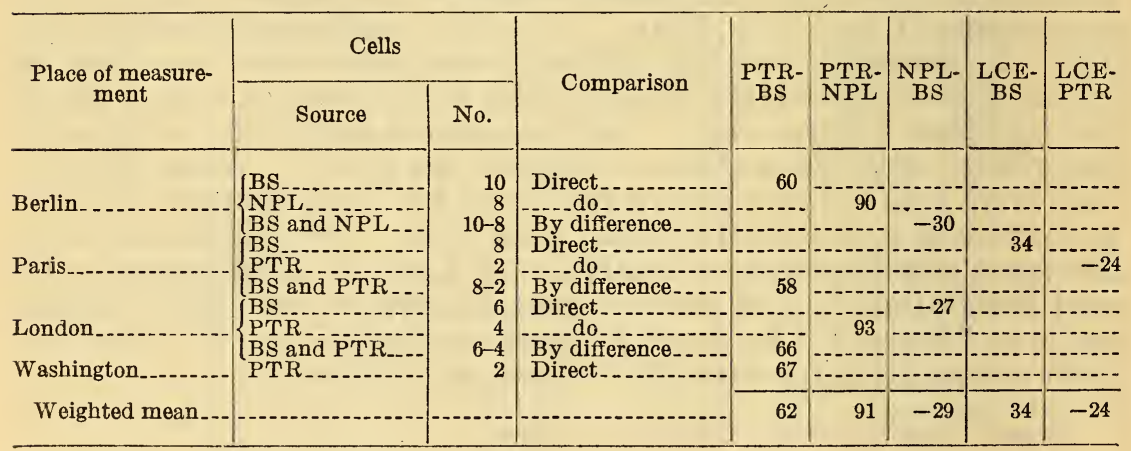

NotE.-Weighted according to number of cells. 


\section{SILVER VOLTAMETER MEASUREMENTS}

The silver voltameter measurements occupied most of the time spent at the Reichsanstalt. The deposits were made and weighed in the constant-temperature room in the observatory.

The shipment of the bureau's voltameter apparatus was made by courtesy of the State Department through the diplomatic pouch and delivered to the embassy in Berlin. The bureau's equipment for the silver voltameter included voltameters of both the Smith form and the porous cup form and a considerable amount of silver nitrate which had been carefully purified. The porous cup voltameter was used on only one occasion, however, in the German laboratory.

\section{ELECTRICAL CIRCUIT}

The electrical circuit is shown diagrammatically in Figure 2. Unlike the arrangements at the Bureau of Standards, the current is allowed to drift, and readings of the potential drop across the standard resistances are taken as changes of 1 part in 100,000 occur. The time of each reading is recorded. At the conclusion of each experi-

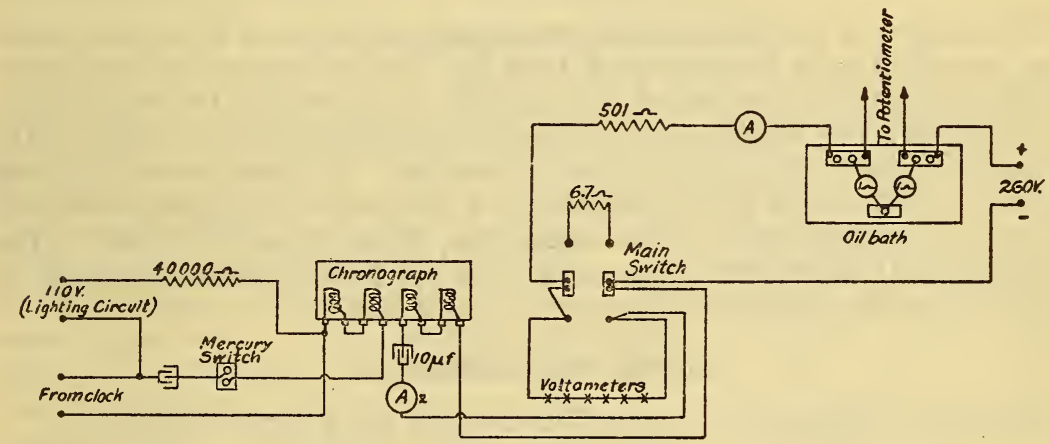

Figure 2.-Voltameter circuit at the Physikalisch-Technische Reichsanstalt

ment the time-voltage data are integrated to obtain the average value of the voltage. Integrations have been made by representatives of each of the laboratories and the results are given in Table 14. The concordance of the results indicates that a high degree of precision can be obtained, but it must be assumed that fluctuations of the current during the first minute or two, and between the subsequent readings, are negligible. Changes in the resistance of the voltameters during the progress of an experiment are largely responsible for the drift of the current and, therefore, the number of voltameters that can be used in any experiment is limited practically to six. Two voltameters of each laboratory were used in each experiment.

$\mathrm{T}_{\mathrm{ABLE}}$ 14.-Integrated value of potentiometer readings during the voltameter experiments

\begin{tabular}{|c|c|c|c|c|c|c|c|}
\hline Experiment No. & $\begin{array}{l}\text { N. P. L. } \\
\text { values }\end{array}$ & $\begin{array}{c}\text { P. T. R. } \\
\text { values }\end{array}$ & $\begin{array}{c}\text { B. S. } \\
\text { values }\end{array}$ & Experiment No. & $\begin{array}{c}\text { N. P. L. } \\
\text { values }\end{array}$ & $\begin{array}{c}\text { P. T. } R \text {. } \\
\text { values }\end{array}$ & $\begin{array}{l}\text { B. S. } \\
\text { values }\end{array}$ \\
\hline 15 & $\begin{array}{l}\text { 1. } 012585 \\
1.017114 \\
1.018145 \\
1.015176 \\
1.015327\end{array}$ & $\begin{array}{l}\text { 1. } 012585 \\
1.017113 \\
1.018146 \\
1.015177 \\
1.015328\end{array}$ & $\begin{array}{l}\text { 1. } 012582 \\
1.017114 \\
1.018145 \\
1.015176 \\
1.015326\end{array}$ & $\begin{array}{l}6 \\
7 \\
8 \\
9 \\
9\end{array}$ & $\begin{array}{l}\text { 1. } 005631 \\
1.019019 \\
1.017457 \\
1.016711 \\
1.018794\end{array}$ & $\begin{array}{l}1.005631 \\
1.019020 \\
1.017458 \\
1.016714 \\
1.018795\end{array}$ & $\begin{array}{l}\text { 1. } 005632 \\
\text { 1. } 019020 \\
\text { 1. } 017458 \\
\text { 1. } 016712 \\
\text { 1. } 018796\end{array}$ \\
\hline
\end{tabular}


The compensating resistance through which the current flowed prior to starting the deposit was adjusted, as nearly as possible, to the initial resistance of the voltameters. The ballast resistance was then set to give a preliminary value of current that was convenient for the potentiometer measurements. The standard resistances were two 1-ohm coils immersed in oil, the temperature of which was read periodically.

The potentiometer was provided with five dials. During the experiment no adjustment of the potentiometer current was made. Its value, however, was such that a normal cell gave a reading of about 1.0183. Periodic readings of a control cell were made during the experiment, and at the conclusion of the experiment the reading of the reference cell was taken for relating the measurements to the primary reference group. The best condition is for the readings during the experiment to involve the same coils in the potentiometer as used for measuring the control and reference cells. This is impractical, however, but the largest differences involve no dials higher than the millivolt dial.

\section{MEASUREMENT OF TIME}

The ticks of a standard clock, omitting $0,15,30$ and 45 second ticks, were recorded on a chronograph tape by the discharge of a condenser. On the same tape a record of the beginning and end of the experiment was made by the discharge of a second condenser (fig. 2) which was charged initially through the voltameters. An ammeter, A2, was placed in series with the condenser as a safeguard to indicate a breakdown of the dielectric in the condenser, if such should occur. The Reichsanstalt estimates the accuracy of the time measurements to be within a few hundredths of a second in two hours.

\section{THE VOLTAMETERS}

Except in experiment 6, the voltameters used were as follows:

\begin{tabular}{|c|c|c|}
\hline Laboratory & Kind of voltameter & $\begin{array}{c}\text { Capacity of platinum } \\
\text { cup }\end{array}$ \\
\hline $\begin{array}{l}\text { B. S } \\
\text { N. P. I } \\
\text { P. T. R }\end{array}$ & $\begin{array}{l}\text { Smith form } \\
\text { Kohlrausch }\end{array}$ & $\begin{array}{rr} & \\
& 350 \\
& 350 \\
& 90\end{array}$ \\
\hline
\end{tabular}

In the sixth experiment the B. S. voltameters were of the porouscup form with small platinum cups, capacity $125 \mathrm{ml}$, and the N. P. L. voltameters were of the Smith form with small cups of $100 \mathrm{ml}$ capacity.

\section{PREPARATION OF PLATINUM CUPS}

Three large platinum cups and three small platinum cups were available for the bureau's part in these experiments. The large cup, No. 93, is one in which no deposits of silver have ever been heated to a sufficiently high temperature to expel inclusions. Cup No. 92, however, had been subject to such treatment. As a result the inner surface of cup No. 92 has been somewhat modified from the condition in which it was used in the work of the international technical committee of 1910. It will be shown in the results that follow that no significant difference was observed in the deposits obtained in these two cups and 
therefore the present work should tie in accurately with the earlier measurements so far as the condition of these platinum cups is concerned. Cup No. 94 was used as a counterpoise in weighing cups Nos. 92 and 93 . Both of the smaller cups, Nos. 27 and 28, had been heated with deposits in determining the inclusions. The counterpoise for weighing the small cups was No. 39.

The platinum cups of the B. S. and N. P. L. voltameters were prepared for each experiment by first removing the previous silver deposit by electrolysis, following which they were filled with nitric acid (1 part acid to 2 parts water) and allowed to stand for about one hour., They were then washed with water, chromic acid, and several changes of distilled water. The B. S. cups were then dried by glowing them in a flame, but the N.P. L. cups were dried in an oven at $120^{\circ} \mathrm{C}$. The glowing process was chosen for the B. S. cups because this had been found effective ${ }^{15}$ in preventing absorption effects in the case of platinum cups in which silver deposits had been heated to high temperatures to expel inclusions. The P. T. R. cups were immersed in a solution of nitric acid and distilled water to dissolve out the silver of the preceding experiment following which they were washed and dried by glowing in a flame.

\section{PREPARING THE ANODES}

The anodes for the B. S. and N. P. L. voltameters were covered with a layer of electrolytic silver that was deposited by electrolysis during the first step in cleaning the platinum cups. This was done by passing a current of about 0.1 ampere through the voltameters in the reverse direction during the night. The silver deposited on the anode was crystalline and adherent. The anodes were washed in distilled water and glowed in a flame. After glowing the electrolytic silver presented a very brilliant appearance. The P. T. R. anodes were solid cylinders of purest silver obtained from the Deutsche Gold- und Silberscheideanstalt in Frankfurt a. M. and were used without depositing electrolytic silver upon them. Following each experiment they were washed and glowed in a flame.

\section{THE ELECTROLYTE}

The B. S. silver nitrate was purified by recrystallization and fusion starting with the chemically pure material of reagent grade available in the bureau's stores. The final tests on the purified product indicated that it was very close to neutral, but on the acid side by less than 1 part in 1,000,000. The permanganate test ${ }^{16}$ for reducing impurities gave values from 6 to 20 minutes without decolorization of one-half $\mathrm{ml}$ of $N / 1,000$ potassium permanganate added to a sample of about $10 \mathrm{~g}$ of silver nitrate in a solution of $10 \mathrm{ml}$. These tests indicate that the silver nitrate for the present investigation was equal to or better than that previously employed for the voltameter work at this bureau.

The silver nitrate used in the B.x. voltameters was a 10 per cent solution and this was freshly prepared for each experiment.

The N. P.L. electrolyte was similarly prepared and tested. As some solutions proved to be slightly basic, small quantities of nitric acid

15 B. S. Bulletin, vol. 13, p. 157, 1915.

16 B. S. Bulletin, vol. 9, p. 531, 1913. 
were added on several occasions. The concentration of the solution for the N. P. L. voltameters was varied at will between 10 and 15 per cent. A fresh solution was prepared for each experiment.

The P. T. R. electrolyte was prepared from fused silver nitrate which was purchased from the Deutsche Gold- und Silberscheideanstalt. Before preparing the solution, however, the sticks were individually washed with distilled water. The P. T. R. solutions were 20 per cent.

For the sixth experiment the solution in all voltameters was 10 per - cent B. S. silver nitrate. For all other experiments the delegates made use of their own material.

Measurements for acidity using methyl red as the indicator were made by the N.P. L. and B. S. delegates and when necessary small corrections have been made to the final values of $E$ calculated from the silver deposits. This has been done in accordance with previous determinations ${ }^{17}$ on the effect of small amounts of acid in decreasing the deposits. Measurements of the acidity of the P. T. R. electrolyte were also made, by permission, and it was found that the solution averaged about 4 parts in $10^{6}$ acid which would permit a correction to the final results of 2 in 100,000 (increase). This correction has not been applied, however, in this report.

\section{WASHING THE DEPOSITS}

At the close of each experiment the glass traps of the Smith form voltameters used by B. S. and N. P. L. were closed and the anodes and anolytes removed. The silver nitrate remaining in the cups was then syphoned off. Following this the cups were filled with distilled water and emptied by syphon six times. The electrolyte and wash waters were examined in a strong light for loose particles of silver. When found, these were added to the respective deposits, but in most cases the electrolyte and wash waters were entirely free of loose particles of silver. After being washed, the cups containing deposits were dried in an oven for one hour or more at $120^{\circ} \mathrm{C}$. When the cups were removed from the oven they were placed in desiccators to cool before weighing.

The P. T. R. voltameters were dismantled at the conclusion of the deposit by removing the anode and glass cup which contained most of the anode slime. The silver nitrate was poured out into a large beaker and the cup filled with distilled water three times. The wash waters were poured into the same beaker with the electrolyte. The platinum cups were then completely immersed in distilled water and allowed to remain so for 24 hours after which they were removed and dried in the oven at $150^{\circ} \mathrm{C}$. The electrolyte and wash waters were filtered through a disk of filter paper in a gooch crucible and the paper examined for loose silver which should be added to the deposits. After drying the deposits the platinum cups were placed in desiccators before weighing them.

\section{WEIGHING THE PLATINUM CUPS}

In preparation for the weighings, two silver weights which are goldplated were recalibrated and the masses certified by the bureau. Actually the weight S2 alone was used in Berlin for weighing deposits

${ }_{17}$ S. B. Bulletin, vol. 10 p. 482, 1913. 
of the Bureau of Standards and those of the National Physical Laboratory. This weight was restandardized at the N.P.L. following the completion of the voltameter experiments in Berlin. The values before and after the measurements are as follows:

$$
\begin{aligned}
& \text { April, B. S. value } \\
& \text { August, N. P. L. value } \\
& \text { (g) }
\end{aligned}
$$

The agreement of the two certified values is therefore very satisfactory. To allow for small variations of a few milligrams in the deposits from the actual value of this standardized weight, a small assay set of weights was employed. This also had been standardized and certified by the bureau.

Weighings were made on a Rueprecht balance in the constanttemperature room. The balance was read by telescope and scale from a distance and was operated by rods and levers. The platinum cups were counterpoised by similar platinum cups and the silver was balanced by the small silver weight mentioned previously. To this was added or subtracted the few milligram weights of the assay set that were necessary to effect a balance. The N. P. L. followed a similar procedure. The P. T. R. cups were weighed against a solid platinum weight and the silver against other weights to which a correction for the buoyancy of the air was applied.

Differences between the cups, deposits, and counterpoises were computed from the swings of the balance. The B. S. and N. P. L. cups were weighed singly against the respective counterpoises and then against each other. The weighings checked in all cases to a few hundredths of a milligram and small residual errors were treated by the method of least squares.

\section{TABLE 15.-Silver deposits}

[Experiment No. 6 B. S. used cups 27 and 28; N. P. L. used cups 4 and 5]

\begin{tabular}{|c|c|c|c|c|c|c|c|c|}
\hline \multirow{2}{*}{ Experiment } & \multicolumn{2}{|c|}{ B. S. voltameters } & \multicolumn{2}{|c|}{ N. P. L. voltameters } & \multicolumn{4}{|c|}{ P. T. R. voltameters } \\
\hline & 93 & 92 & 1 & 3 & 1 & 2 & 3 & 4 \\
\hline \multirow{4}{*}{$\begin{array}{l}1 \\
2 \\
3 \\
4 \\
5\end{array}$} & \multirow{4}{*}{$\begin{array}{c}m g \\
4,091.89 \\
4,093.28 \\
4,096.00 \\
4,085.56 \\
4,086.15\end{array}$} & \multirow{4}{*}{$\begin{array}{c}m g \\
4,091.72 \\
4,093.17 \\
4,095.91 \\
4,085.43 \\
4,086.21\end{array}$} & \multirow{4}{*}{$\begin{array}{c}m g \\
4,091.88 \\
4,093.47 \\
(4,096.50) \\
4,085.35 \\
4,085.98\end{array}$} & \multirow{4}{*}{$\begin{array}{c}m g \\
4,091.65 \\
4,093.46 \\
(4,096.83) \\
4,085.38 \\
4,086.12\end{array}$} & \multirow[t]{2}{*}{${ }_{4,092.37}^{m g}$} & \multirow[t]{2}{*}{$\begin{array}{c}m g \\
4,092.61\end{array}$} & $m g$ & $m g$ \\
\hline & & & & & & & \multirow{2}{*}{$4,092.90$} & \multirow{2}{*}{$4,092.82$} \\
\hline & & & & & $4,095.97$ & $4,095.77$ & & \\
\hline & & & & & $4,086.23$ & $4,086.11$ & T, 000.10 & $4,085.40$ \\
\hline \multirow{4}{*}{$\begin{array}{l}6 \\
7 \\
8 \\
9 \\
9\end{array}$} & \multirow{4}{*}{$\begin{array}{l}4,080.74 \\
4,101.20 \\
4,094.95 \\
4,091.05 \\
4,168.14\end{array}$} & \multirow{4}{*}{$\begin{array}{l}4,080.59 \\
4,101.23 \\
4,095.07 \\
4,091.10 \\
4,168.24 \\
\end{array}$} & \multirow{4}{*}{$\begin{array}{l}4,081.44 \\
4,101.16 \\
4,094.95 \\
4,091.16 \\
4,168.15 \\
\end{array}$} & \multirow{4}{*}{$\begin{array}{l}4,081.38 \\
4,101.22 \\
4,094.83 \\
4,091.27 \\
4,168.11\end{array}$} & \multirow{2}{*}{$4,101.57$} & \multirow{2}{*}{$4,101.75$} & \multirow[t]{2}{*}{$4,080.16$} & $4,080.17$ \\
\hline & & & & & & & & \multirow{2}{*}{$4,094.53$} \\
\hline & & & & & \multirow{2}{*}{$\begin{array}{r}4,091.50 \\
-\end{array}$} & \multirow{2}{*}{$4,091.18$} & & \\
\hline & & & & & & & $4,168.16$ & $4,168.10$ \\
\hline Sum. & $40,988.96$ & $40,888.67$ & $40,990.04$ & $40,990.25$ & $20,467.64$ & $20,467.42$ & $20,520.98$ & $20,521.02$ \\
\hline Total & \multicolumn{2}{|c|}{$81,977.63$} & \multicolumn{2}{|c|}{$81,980.29$} & \multicolumn{4}{|c|}{$81,977.06$} \\
\hline
\end{tabular}

Note.-Maximum difference of total deposits 4 in 100,000.

\section{THE SILVER DEPOSITS}

Table 15 records the silver deposits and shows how reproducible the voltameter deposits are assuming there is no error from any other source. 
The two B. S. voltameters agreed to within $0.3 \mathrm{mg}$ of silver in a total for the 10 deposits of $41 \mathrm{~g}$ of silver in each cup. The total deposits in the B. S. and P. T. R. voltameters agreed to within 0.6 $\mathrm{mg}$ in $82 \mathrm{~g}$ of silver. It has been necessary to include in the addition several determinations (bracketed values in table) which were rejected in computing the final results, but notwithstanding this, the agreement of the sum totals of the weights of deposits in voltameters of the three countries is good.

\section{FINAL RESULTS WITH THE VOLTAMETERS}

The final results for the electromotive force of the P. T. R. Kleiner Stamm using the P. T. R. "international ohm" are given in Table 16. The values from one experiment to the next seem to scatter more than would be expected from the concordance of the silver deposits listed in Table 15. These final values involve the errors in measuring the current and time as well as the errors in the voltameters themselves. It appears that the errors in measuring current and time are greater than in the manipulation of the voltameter.

TABLE 16.-Silver voltameter results at the Physikalisch-Technische Reichsanstalt [Measurement of the emf. of the Kleiner Stamm in terms of the silver deposits and the P. T. R. international ohm]

\begin{tabular}{|c|c|c|c|c|c|c|c|c|c|}
\hline \multirow{2}{*}{ Date } & \multicolumn{3}{|c|}{ B. S. voltameters } & \multicolumn{3}{|c|}{ N. P. L. voltameters } & \multicolumn{3}{|c|}{ P. T. R. voltameters } \\
\hline & Emf & $\Delta$ & Weight & Emf & $\Delta$ & Weight & Emf & $\Delta$ & Weigh \\
\hline 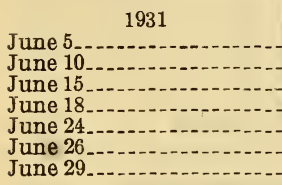 & $\begin{array}{r}1.01812 \\
30 \\
23 \\
23 \\
22 \\
15 \\
24\end{array}$ & $\begin{array}{r}-8 \\
+10 \\
+3 \\
+3 \\
+2 \\
-5 \\
+4\end{array}$ & $\begin{array}{r}2 \\
10 \\
10 \\
10 \\
10 \\
2 \\
10\end{array}$ & $\begin{array}{r}1.01811 \\
36 \\
\text { (basic) }[40] \\
20 \\
18 \\
33 \\
23\end{array}$ & \begin{tabular}{r}
-10 \\
+15 \\
\hdashline-1 \\
-3 \\
+12 \\
+2
\end{tabular} & $\begin{array}{r}10 \\
10 \\
2 \\
10\end{array}$ & $\begin{array}{r}1.01828 \\
21 \\
21 \\
17 \\
21 \\
03 \\
35\end{array}$ & $\begin{array}{l}+9 \\
+2 \\
+2 \\
-2 \\
+2 \\
-16 \\
+16\end{array}$ & $\begin{array}{r}10 \\
10 \\
10 \\
10 \\
2 \\
10\end{array}$ \\
\hline $\begin{array}{l}\text { July } \\
\text { July } 6 \\
\text { July } 9\end{array}$ & $\begin{array}{l}26 \\
07 \\
15\end{array}$ & $\begin{array}{r}+6 \\
-13 \\
-5\end{array}$ & $\begin{array}{l}10 \\
10 \\
10\end{array}$ & $\begin{array}{l}24 \\
11 \\
13\end{array}$ & $\begin{array}{r}+3 \\
-10 \\
-8\end{array}$ & $\begin{array}{l}10 \\
10 \\
10\end{array}$ & 17 & $\begin{array}{l}-2 \\
-6 \\
-6\end{array}$ & $\begin{array}{l}10 \\
10 \\
10\end{array}$ \\
\hline Mean & 1.01820 & 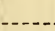 & $-\alpha$ & 1.01821 & -1 & .....- & 1.01819 & - & \\
\hline $\begin{array}{l}\text { Probable error of single } \\
\text { observation }\end{array}$ & 48 & & & 50 & & & 59 & & \\
\hline Weighted mean. & $1.01820 \mathrm{~g}$ & & & 1. $01820 \mathrm{~g}$ & & & $1.01819_{5}$ & & \\
\hline
\end{tabular}

Summary

B. S. voltameters
N. P. T. R. voltameters voltameters...
$\quad$ Mean of all
$\quad$ Probable error

The mean results of 10 experiments show a very satisfactory agreement between the B. S., N. P. L., and P. T. R. voltameters. The mean of all is 1.01820 with a probable error of 1 part in 100,000.

At the close of the work, a conference was held at which the following were present: Prof. Dr. Giebe, chairman; Prof. Dr. Jaeger; Prof. Dr. von Steinwehr; Mr. Vigoureux; and Mr. Vinal. 
It was agreed that-

1. The present work supports the conclusions of the International Technical Committee of 20 years ago in establishing the electromotive force of the Weston normal cell as 1.0183 volts at $20^{\circ}$ in terms of international units.

2. The present comparison of standard cells and the voltameter results are concordant in indicating that the P. T. $R$. unit for the volt at the time of these measurements was too low by about 1 in 10,000 .

\section{DISCUSSION OF THE DIFFERENCES IN THE UNITS}

When the silver voltameter is used to determine the value to be assigned to a group of standard cells or to verify a value previously determined, it is necessary to employ also standards of resistance for which values are known in terms of some specified unit. The differences which may be observed from time to time in the value of electromotive force of a group of cells by voltameter measurements include, therefore, changes in the unit for the ohm as well as changes in the electromotive force of the cells. The value determined in the course of this work for the electromotive force of the Kleiner Stamm at the Reichsanstalt is based on the P. T. R. standard for the international ohm and the mean result of the voltameter measurements by representatives of the three laboratories. The concordance of the voltameter measurements indicates that the international ampere as defined by the silver deposits of the three laboratories is the same to within 1 part in 100,000 .

Direct comparisons of standards of electromotive force and resistance have revealed much larger differences to exist between the various laboratories. The voltameter measurements by the three laboratories jointly in Berlin fulfill the recommendation ${ }^{18}$ of the Advisory Committee on Electricity to the International Committee on Weights and Measures.

In the course of ordinary electrical measurements, the international ampere is based on measurements of electromotive force $(E)$ and resistance $(R)$ and not on the "silver ampere" of the voltameter, although that is the fundamental unit. In Figure 1 are given diagrammatically the differences in millionths which have been found for the ampere based on measurements of $E$ and $R$ at the several laboratories. These differences are greater than for either $E$ or $R$ singly because both are involved.

The watt which is derived from measurements of $E$ and $R$ in the course of ordinary work involves the differences in $R$ and twice the differences in $E$ as may be seen by writing the formula

$$
W=\frac{E^{2}}{R}
$$

It is not surprising, therefore, that the differences in the watt as measured at the several laboratories are greater than for the other units. The maximum difference is 198 millionths as shown in Figure 1.

Since direct comparisons of the ohm and volt standards were made, it is possible to translate the voltameter results into the approximate

${ }_{18}$ Report, Comité Consultatif d'Électricité, p. 23, 1930.

117348-32-6 
values which would have been obtained at Paris, Teddington, or Washington, if the voltameter measurements had been made in those places, employing the reference groups of cells and resistance standards of the respective laboratories. The results are as follows:

TABLE 17.-Observed and calculated values of the standards of electromotive force at the four laboratories

\begin{tabular}{|c|c|c|c|}
\hline Place & Units & $\begin{array}{l}\text { Emf at } \\
20^{\circ} \mathrm{C} \text {. }\end{array}$ & Remarks \\
\hline 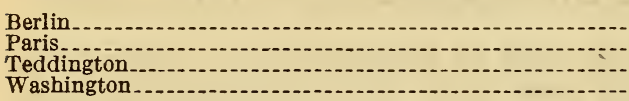 & $\begin{array}{l}\text { P. T. R. R. } \\
\text { L. C. } \mathrm{E} \cdot \mathrm{N} \\
\text { N. P. } \mathrm{L} \\
\text { B. S. }\end{array}$ & $\begin{array}{l}1.01820 \\
1.01817 \\
1.01830 \\
1.01827\end{array}$ & $\begin{array}{l}\text { Observed. } \\
\text { Calculated. } \\
\text { Do. } \\
\text { Do. }\end{array}$ \\
\hline
\end{tabular}

The inference drawn from these results is that the unit of the N. P. L. corresponds exactly to the value defined for the Weston normal cell at $20^{\circ} \mathrm{C}$. by the International Technical Committee of 20 years ago. The units for the other laboratories are slightly lower. The value for Washington in terms of B. S. units is, however, exactly the same as the result of the bureau's own experiments on the voltameter ${ }^{19}$ published in 1913. The value observed in Berlin in P. T. R. units is less than the electromotive force determined ${ }^{20}$ for the Kleiner Stamm when voltameter measurements were last made there by approximately 1 in 10,000 . No previous figures on the L. C. E. standard are available for comparison.

\section{CONCLUSIONS}

1. The comparisons which have been made between the standards for the international electrical units of four national laboratories have shown significant differences to exist, although a uniform basis for the international units was provided by the agreement among the laboratories, effective January 1, 1911.

2. The maximum difference for the international ohm, as the unit is maintained at these laboratories, is 74 millionths. Two laboratories have recently corrected their measurements by about 3 in 100,000 as a result of their latest mercury-ohm determinations. These corrections, however, fall within the maximum limits of the difference mentioned above.

3. The standards for the volt, which are groups of Weston normal cells, differ in electromotive force by as much as 1 part in 10,000. A highly concordant series of voltameter experiments has now been made which confirms the recommendation of the International Technical Committee in defining the electromotive force of the Weston normal cell as 1.0183 international volts at $20^{\circ} \mathrm{C}$. These same voltameter measurements indicate that the groups of cells having the lower values at the present time are appreciably below the normal value.

4. The international ampere as determined by the silver deposits of three of the national laboratories is the same to within 1 part in 100,000 . The agreement on this fundamental unit indicates that a 
readjustment in the electromotive force assigned to certain groups of cells may safely be made.

5. At the present time, the international ampere used in ordinary measurements is based on working standards of electromotive force and resistance. These differ as mentioned above and, therefore, the working representation of the international ampere of the several laboratories based on $E$ and $R$, differs by as much as 136 millionths. This difference could be much reduced by a readjustment of values assigned to the working standards of electromotive force and resistance.

6. The unit of power, the watt, is usually measured in terms of $E$ and $R$ and, therefore, involves twice the differences that have been found in standards for the former and also the differences in standards for the latter. The maximum spread in the unit for the watt between the several laboratories is 198 millionths.

7. The results of the present work indicate that a readjustment of the values assigned to standards for the ohm and volt is needed. Such a step is not to be taken ill-advisedly, however, but after agreement of properly constituted authorities. The question involved has broader aspects than a mere readjustment of values assigned to standards on the basis of the international units. Other investigations on the absolute measurement of the ohm and the ampere, the discussion of which is outside of the scope of this paper, have shown that the international standards for the ohm and, consequently, the volt also do not represent the absolute units of resistance and electromotive force as closely as was believed 20 years ago. The Advisory Committee on Electricity to the International Committee on Weights and Measures has expressed its opinion in the first report dated February 11,1929, that the absolute system of electrical units based on the cgs system ought to replace the present international system for all scientific and industrial determinations.

If this is to be done, the change in the units for the ohm and the volt will amount to 5 parts in 10,000, which is much larger than the present discrepancies between the international standards. Rather. than make two adjustments of the electrical standards in the next few years, the present discrepancies seem an added argument for passing quickly to the absolute basis for the units by a single adjustment of values. Such a step would unify the systems of mechanical, thermal, and electrical measurements on a sound theoretical basis, but would not lessen the vigilance required of the national laboratories to preserve the constancy and equality of the working standards. There seems little doubt that the working standards of the future, as in the past, will be wire standards of resistance and the Weston normal cell. The results of the present work emphasize the necessity for close cooperation between the national laboratories in order that correct and uniform electrical standards may be maintained.

Washington, March 16, 1932. 